\title{
Simultaneous determination of selected flavonoids from different Cistus species by HPLC-PDA
}

\author{
Perihan GÜRBÜZ ${ }^{1 *}$, Müberra KOŞAR ${ }^{2}$, Zühal GÜVENALP ${ }^{3}$, Ayşe KURUÜZÜM UZ ${ }^{4}$, \\ Lütfiye Ömür DEMİREZER ${ }^{4}$
}

1 Department of Pharmacognosy, Faculty of Pharmacy, Erciyes University, Kayseri, Turkey.

2 Department of Pharmacognosy, Faculty of Pharmacy, Eastern Mediterranean University, Gazimagusa, Turkish Republic of Northern Cyprus-via Mersin 10 Turkey.

3 Department of Pharmacognosy, Faculty of Pharmacy, Atatürk University, Erzurum, Turkey.

4 Department of Pharmacognosy, Faculty of Pharmacy, Hacettepe University, Ankara, Turkey.

* Corresponding Author. E-mail: pgurbuz@erciyes.edu.tr (P.G.); Tel. +90-352-207 66 66; ORCID No: 0000-0002-3056411X.

Received: 23 January 2018 / Revised: 02 May 2018 / Accepted: 04 May 2018

ABSTRACT: A rapid and simple high-performance liquid chromatography method with a Photo Diode Array (PDA) detector is developed for the simultaneous analysis of seven kaempferol, quercetin and myricetin derivatives along with an acylated flavonoid glycoside; trans-tiliroside from different Cistus species. In this study, the qualitative and quantitative analysis of the methanolic extracts of three Cistus species (C. creticus L., C. laurifolius L. and C. salviifolius L.) growing in Anatolia in terms of characterization of flavonoid compounds were performed by RP-HPLC for the first time. Trans-tiliroside, a mono-coumaroyl kaempferol glucoside was found to be the most abundant flavonoid in $C$. salviifolius $\left(0.276 \pm 0.003 \mathrm{~g} / 100 \mathrm{~g}_{\text {extract }}\right)$ and C. creticus $\left(0.253 \pm 0.001 \mathrm{~g} / 100 \mathrm{~g}_{\text {extract }}\right)$ while hyperin $(0.149 \pm 0.004 \mathrm{~g} / 100 \mathrm{~g}$ extract $)$ and myricetin 3-O- $\beta$-galactopyranoside $(0.139 \pm 0.006 \mathrm{~g} / 100 \mathrm{~g}$ extract $)$ were found to be the most intense flavonoids in $C$. laurifolius samples. The described HPLC method appears suitable for the determination of the Cistus flavonols and their glycosides and can be considered as an effective and alternative procedure for the identification and quantification of this important class of biologically active compounds.

KEYWORDS: Cistus; Cistaceae; flavonols; HPLC-PDA.

\section{INTRODUCTION}

The genus Cistus (Cistaceae) comprises more than 20 species distributed mainly in Mediterranean countries and five species with no endemism in Flora of Turkey [1,2]. Cistus species are characteristic and important ecological elements of the shrubs and degraded forests with post fire and/or mining threats [3]. Cistus species have widespread utilization in Turkish folk medicine to cure some ailments like rheumatism, stomachache, hemorrhoids, sterility, urinary inflammations, peptic ulcer and diabetes mellitus [4, 5]. Pharmacological activities including cytotoxic [6, 7], antinociceptive, hepatoprotective [8, 9] anti-microbial [10, 11], anti-viral $[12,13]$, anti-inflammatory $[9,14,15]$, antioxidant $[16,17]$, analgesic $[9,18,19]$, spasmolytic [2022], anti-ulcerogenic, gastro protective [23-25], and antihyperglycemic [26] activities of Cistus species have been reported. Labdane type diterpenes [7, 27, 28], flavonoids [9, 29] flavanols and proanthocyanidins [30-32] were isolated from different Cistus species as active compounds.

Many qualitative and quantitative analytical studies were coupled with the determination of phenolic, polyphenolic and flavonoid composition from different Cistus species [29, 33-35]. Herein an HPLC-PDA method was used for qualitative and quantitative analyses of seven flavonoids (Figure 1) which were previously isolated from aerial parts of $C$. salviifolius [36]; simultaneously in three different Cistus species (C. creticus, C. laurifolius and C. salviifolius).

\section{RESULTS AND DISCUSSION}

In the present study, the qualitative and quantitative analysis of selected flavonoids in different Cistus species originated from Anatolia were carried out for the first time. Since there is an attention in Cistus

How to cite this article: Gürbüz P, Koşar M, Güvenalp Z, Kuruüzüm Uz A, Demirezer EÖ. Simultaneous determination of selected flavonoids from different Cistus species by HPLC-PDA. Marmara Pharm J. 2018; 22 (3): 405-410. 
preparations, it is understood that the rapid and effective analyze of active principles of those species plays a crucial role. The chromatograms of the standard flavonoids mixture and three different Cistus species were given in Figure 2. Both the retention times and UV spectra were used to identify the compounds. The results of the amounts of these flavonoids in the extracts were summarized in Table 1 . The extraction and purification procedures (total time $100 \mathrm{~min}$ ) tested in this work enabled rapid analysis of the flavonol pool (Fig. 1) in Cistus species were ready for HPLC analysis within one day's work. The quantities of the compounds identified in the extracts were determined using calibration curves prepared from standard flavonoids. The results indicated that kaempferol stayed under the limit of detections in all tested samples and quercetin in $C$. salviifolius as well. For all that trans-tiliroside, a mono-coumaroyl kaempferol glucoside, was found to be the most abundant flavonoid in C. salviifolius $\left(0.276 \pm 0.003 \mathrm{~g} / 100 \mathrm{~g}_{\text {extract }}\right)$ and C. creticus $\left(0.253 \pm 0.001 \mathrm{~g} / 100 \mathrm{~g}_{\text {extract }}\right)$; while hyperin $\left(0.149 \pm 0.004 \mathrm{~g} / 100 \mathrm{~g}_{\text {extract }}\right)$ and myricetin $3-O-\beta$-galactopyranoside $\left(0.139 \pm 0.006 \mathrm{~g} / 100 \mathrm{~g}_{\text {extract }}\right)$ were found to be the most intense flavonoids in C. laurifolius samples.

Table 1. Quantitative determination of flavonols in Cistus samples.

\begin{tabular}{|c|c|c|c|c|c|}
\hline \multirow{2}{*}{ Comp. } & \multirow{2}{*}{ Standard curve } & \multirow{2}{*}{$\mathbf{r}^{2}$} & \multicolumn{3}{|c|}{ Cistus samples* } \\
\hline & & & CS & CC & CL \\
\hline S1 & $y=12967 x-26.011$ & 0.997 & $0.076 \pm 0.003$ & $0.066 \pm 0.000$ & $0.139 \pm 0.006$ \\
\hline S2 & $y=9587.7 x-0.211$ & 0.999 & $0.157 \pm 0.003$ & $0.047 \pm 0.001$ & $0.149 \pm 0.004$ \\
\hline S3 & $y=9402.1 x-29.260$ & 0.999 & $0.079 \pm 0.001$ & $0.024 \pm 0.000$ & $0.039 \pm 0.001$ \\
\hline S4 & $y=14658 x+114.74$ & 0.996 & nd. & $0.027 \pm 0.000$ & $0.012 \pm 0.001$ \\
\hline S5 & $y=166.43 x-55.840$ & 0.999 & $0.009 \pm 0.000$ & $0.007 \pm 0.000$ & $0.008 \pm 0.000$ \\
\hline S6 & $y=3844.2 x-8.092$ & 0.999 & $0.276 \pm 0.003$ & $0.253 \pm 0.001$ & $0.114 \pm 0.002$ \\
\hline S7 & $y=39479 x+88.737$ & 0.996 & nd. & nd. & nd. \\
\hline
\end{tabular}<smiles>[R]c1cc(-c2oc3cc(O)cc(O)c3c(=O)c2O)cc([R2])c1O</smiles>

$\begin{array}{llll} & \text { R1 } & \text { R2 } & \text { R3 } \\ \text { S1 } & \text { OH } & \text { OH } & \beta \text {-galactopyranose } \\ \text { S2 } & \text { OH } & \text { H } & \beta \text {-galactopyranose } \\ \text { S3 } & \text { OH } & \text { H } & \alpha \text {-arabinopyranose } \\ \text { S4 } & \text { OH } & \text { H } & \text { H } \\ \text { S5 } & \text { OH } & \text { OH } & \text { H } \\ \text { S6 } & \text { H } & \text { H } & \beta \text {-(6"-O-trans-p-coumaroyl)-glucopyranose } \\ \text { S7 } & \text { H } & \text { H } & \text { H }\end{array}$

Figure 1. Structures of compounds S1-S7. S1 (myricetin 3-O- $\beta$-galactopyranoside), S2 (hyperin), S3 (guaijaverin), S4 (quercetin), S5 (myricetin), S6 (trans-tiliroside), S7 (kaempferol).

According to the recently published paper by Tohge et al., flavonoid production in land plants induced by light stress as well as the phenyl acylation of flavonoids was found to confer enhanced phytochemical functions as UV-B protectants in plants [37]. Probably that's why trans-tiliroside was found to be the most abundant flavonoid in two tested samples which were collected from the hillsides over $600 \mathrm{~m}$ altitudes.

The analytical studies on different Cistus species i.e. C. ladanifer, C. laurifolius, C. salviifolius, C. incanus and C. monspeliensis are mostly conducted on different classes of flavonoids such as flavanols, catechins and ellagitannins etc. [29, 33-35]. In the present study, different derivatives of flavonols isolated previously from Cistus salviifolius were selected and standardization of the methanol extracts of three Cistus species were achieved for the first time using a simple and efficient HPLC-PDA method. To understand the effect of the 
environmental conditions to the flavonol production of Cistus species, it is necessary to collect a large and diverse number of samples from different regions and repeat this analytical study with this fast and efficient method described above.
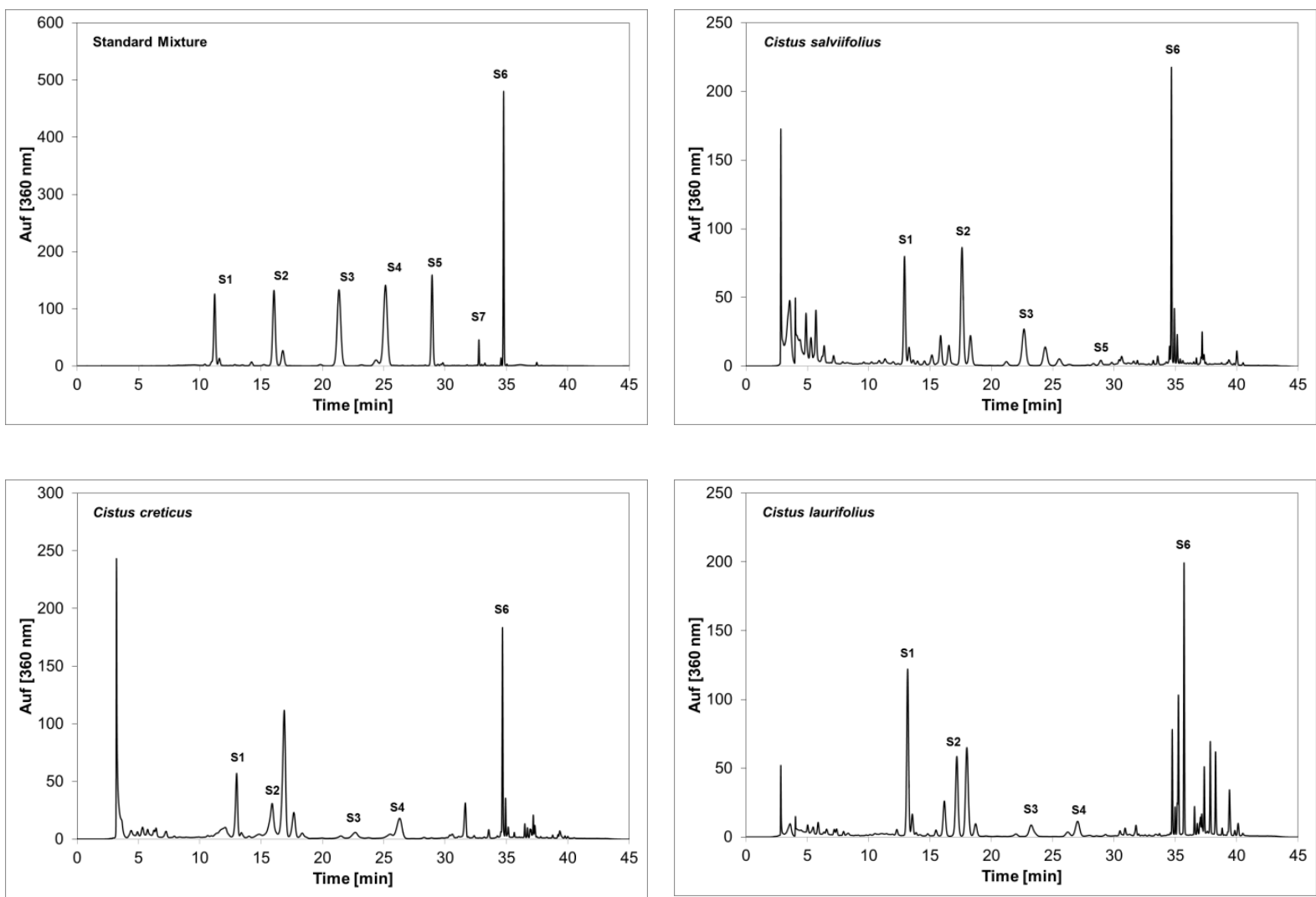

Figure 2. HPLC-PDA analyses of standard flavonoid mixture and Cistus extracts with responses at $360 \mathrm{~nm}$; S1(myricetin 3-O- $\beta$-galactopyranoside), S2 (hyperin), S3 (guaijaverin), S4 (quercetin), S5 (myricetin), S6 (trans-tiliroside), S7 (kaempferol).

\section{CONCLUSION}

As a consequence, Mediterranean shrubs like Cistus species not only serve an important ecological function in the equilibrating of highly-damaged ecosystems, but also may be a very valuable source of bioactive flavonoids with potential use in human healthcare.

\section{MATERIALS AND METHODS}

\subsection{Chemicals}

Chromatographic grade distillated water, HPLC grade methanol (Merck, 106007) analytical grade ophosphoric acid (Merck, 100573) and HPLC grade acetonitrile (Merck, 100030) were used for HPLC analyses. All either chemical were supplied from either Sigma or Merck. All flavonoids are isolated from C. salviifolius namely myricetin 3-O- $\beta$-galactopyranoside (S1), quercetin 3-O- $\beta$-galactopyranoside (hyperin) (S2), quercetin 3-O-a-arabinopyranoside (guaijaverin) (S3), quercetin (S4), myricetin (S5), kaempferol 3-O- $\beta$-(6"-O-trans- $p$ coumaroyl)-glucopyranoside (trans-tiliroside) (S6) and kaempferol (S7).

\subsection{Plant Material}

The aerial parts of Cistus salviifolius L., C. creticus L. were harvested from Mahmutlar, Alanya province in April 2009. C. laurifolius L. was collected from Afyon-Eskişehir road in June 2009. All plant samples were identified by Dr. Z. Ceren Arituluk. The voucher specimens are stored in the Herbarium at the Faculty of Pharmacy, Hacettepe University, Ankara, Turkey (HUEF 09002, HUEF 09003 and HUEF 10085, respectively). 


\subsection{Extraction \& Sample Preparation}

The air dried and powdered aerial parts of Cistus species $(5 \mathrm{~g})$ were extracted with $70 \% \mathrm{MeOH}$ at $37^{\circ} \mathrm{C}$ $(10 \mathrm{~mL} \times 3)$. Thereafter the extracts were filtered and evaporated to dryness in vacuo $37^{\circ} \mathrm{C}$ [yields of $C$. salviifolius (CS): $12 \%$, C. creticus (CC): $12 \%$, C. laurifolius (CL): $14 \%$ ]. All extracts were stored at $-20{ }^{\circ} \mathrm{C}$ until analyses. Prior to analysis, $10 \mathrm{mg}$ of each extract was dissolved in $1 \mathrm{~mL}$ of $70 \% \mathrm{MeOH}$ and filtered through a $0.45 \mu \mathrm{m}$ membrane and used in all the HPLC analyses.

\subsection{Qualitative-Quantitative Chromatographic Analysis}

The high performance liquid chromatographic apparatus (Agilent, 1200) consisted of an in-line degasser, pump and controller coupled to a SPD-M10Avp photo diode array detector equipped with an automatic injector interfaced to Class VP chromatography manager software. Separations were performed on a $250 \times 4.6 \mathrm{~mm}, 5 \mu \mathrm{M}$ particle size, reverse-phase Teknokroma Sea 18 Mediterranean analytical column (Shimadzu-N48409) operating at room temperature $\left(22^{\circ} \mathrm{C}\right)$ at a flow rate of $1 \mathrm{~mL} / \mathrm{min}$. Detection was carried out with a sensitivity of 0.1 aufs (absorbance units full scale) between 200 and $550 \mathrm{~nm}$. Elution was carried out using a ternary non-linear gradient of the solvent mixture $0-\mathrm{H}_{3} \mathrm{PO}_{4}(0.5 \%$ in distilled water) (solvent $\mathrm{A})$ and $\mathrm{CH}_{3} \mathrm{CN}$ (solvent $\mathrm{B}$ ). The $15 \%$ solvent $\mathrm{B}$ held for 5 minutes and increased to $20 \%$ in 5 min and held there for 12 min, increased to $35 \%$ in $8 \mathrm{~min}$ and increased to $75 \%$ in $5 \mathrm{~min}$ and held there for $5 \mathrm{~min}$ and returned to the initial conditions in $2 \mathrm{~min}$. Components were identified by comparison of their retention times to those of authentic standards under identical analysis conditions and UV spectra using our in-house photo diode array detector (PDA) library. A 10 min equilibrium time was allowed between injections. All standards and sample solutions were injected three times. Standard flavonoids (S1-S7) were prepared in methanol and for each compounds at least five different concentration levels $(0.01-0.30 \mathrm{mg} / \mathrm{mL})$ were injected for the establishment of calibration curves (Table 1).

Author contributions: Concept - P.G.; Design - P.G.; M.K; Supervision - P.G.; Resource - P.G.; L.Ö.D.; A.K.U.; Z.G. Materials - P.G.; L.Ö.D.; A.K.U.; Z.G.; Data Collection and/or Processing - P.G.; M.K.; Analysis and/or Interpretation - P.G.; M.K.; Literature Search - P.G.; Writing - P.G.; Critical Reviews - P.G.M.K.; L.Ö.D.; A.K.U; Z.G.

Conflict of interest statement: The authors declared no conflict of interest.

\section{REFERENCES}

[1] Coode MJE. Cistaceae. In P.H. Davis, Editor. Flora of Turkey and the East Aegean Islands. Edinburgh University Press: Edinburgh. 1965-1985, vol:1, pp. 506-523.

[2] Coode MJE. Cistaceae. In P.H. Davis, Mill, R., Tan, K., Editor. Flora of Turkey and the East Aegean Islands. Edinburgh University Press: Edinburgh. 1988, vol:10 pp. 61.

[3] Roy J, Sonie L. Germination and population dynamics of Cistus species in relation to fire. J Appl Ecol. 1992: 647-655.

[4] Baytop T, Therapy with Medicinal Plants in Turkey (Past and Present), Publications of the Istanbul University, İstanbul, 1984.

[5] Yeşilada E, Honda G, Sezik E, Tabata M, Fujita T, Tanaka T, Takeda Y, Takaishi Y. Traditional medicine in Turkey. V. Folk medicine in the inner Taurus Mountains. J Ethnopharmacol. 1995; 46(3): 133-152.

[6] Barrajón-Catalán E, Fernández-Arroyo S, Saura D, Guillén E, Fernández-Gutiérrez A, Segura-Carretero A, Micol V. Cistaceae aqueous extracts containing ellagitannins show antioxidant and antimicrobial capacity, and cytotoxic activity against human cancer cells. Food Chem Toxicol. 48(8-9): 2273-2282.

[7] Demetzos C, Mitaku S, Couladis M, Harvala C, Kokkinopoulos D. Natural metabolites of ent-13-epi-Manoyl Oxide and other cytotoxic diterpenes from the resin "LADANO" of Cistus creticus. Planta Med. 1994; 60(6): 590-591.

[8] Kupeli E, Orhan DD, Yesilada E. Effect of Cistus laurifolius L. leaf extracts and flavonoids on acetaminophen-induced hepatotoxicity in mice. J Ethnopharmacol. 2006; 103(3): 455-460.

[9] Kupeli E., Yesilada E. Flavonoids with anti-inflammatory and antinociceptive activity from Cistus laurifolius L. leaves through bioassay-guided procedures. J Ethnopharmacol. 2007; 112(3): 524-530.

[10] Bouamama H, Noel T, Villard J, Benharref A, Jana M. Antimicrobial activities of the leaf extracts of two Moroccan Cistus L. species. J Ethnopharmacol. 2006; 104(1-2): 104-107. 
[11] Guvenc A, Yildiz S, Ozkan AM, Erdurak CS, Coskun M, Yilmaz G, Okuyama T, Okada Y. Antimicrobiological studies on Turkish Cistus species. Pharm Biol. 2005; 43(2): 178-183.

[12] Kalus U, Grigorov A, Kadecki O, Jansen JP, Kiesewetter H, Radtke H. Cistus incanus (CYSTUS052) for treating patients with infection of the upper respiratory tract A prospective, randomised, placebo-controlled clinical study. Antivir Res. 2009; 84(3): 267-271.

[13] Kalus U, Kiesewetter H, Radtke H. Effect of CYSTUS052 (R) and green tea on subjective symptoms in patients with infection of the upper respiratory tract. Phytother Res. 2010; 24(1): 96-100.

[14] Sadhu SK, Okuyama E, Fujimoto H, Ishibashi M, Yesilada E. Prostaglandin inhibitory and antioxidant components of Cistus laurifolius, a Turkish medicinal plant. J Ethnopharmacol. 2006; 108(3): 371-378.

[15] Yesilada E, Ustun O, Sezik E, Takaishi Y, Ono Y, Honda G. Inhibitory effects of Turkish folk remedies on inflammatory cytokines: interleukin-1alpha, interleukin-1beta and tumor necrosis factor alpha. J Ethnopharmacol. 1997; 58(1): 59-73.

[16] Attaguile G, Russo A, Campisi A, Savoca F, Acquaviva R, Ragusa N, Vanella A. Antioxidant activity and protective effect on DNA cleavage of extracts from Cistus incanus L. and Cistus monspeliensis L. Cell Biol Toxicol. 2000; 16(2): 8390.

[17] Qa'Dan F, Petereit F, Mansoor K, Nahrstedt A. Antioxidant oligomeric proanthocyanidins from Cistus salvifolius. Nat Prod Res. 2006; 20(13): 1216-1224.

[18] Ark M, Ustun O, Yesilada E. Analgesic activity of Cistus laurifolius in mice. Pharm Biol. 2004; 42(2): 176-178.

[19] De Andres AI, Gomez-Serranillos MP, Iglesias I, Villar AM. Effects of extract of Cistus populifolius L. on the central nervous system. Phytother Res. 1999; 13(7): 575-579.

[20] Attaguile G, Perticone G, Mania G, Savoca F, Pennisi G, Salomone S. Cistus incanus and Cistus monspeliensis inhibit the contractile response in isolated rat smooth muscle. J Ethnopharmacol. 2004; 92(2-3): 245-250.

[21] Aziz M, Tab N, Karim A, Mekhfi H, Bnouham M, Ziyyat A, Melhaoui A, Legssyer A. Relaxant effect of aqueous extract of Cistus ladaniferus on rodent intestinal contractions. Fitoterapia. 2006; 77(6): 425-428.

[22] Belmokhtar M, Bouanani NE, Ziyyat A, Mekhfi H, Bnouham M, Aziz M, Mateo P, Fischmeister R, Legssyer A. Antihypertensive and endothelium-dependent vasodilator effects of aqueous extract of Cistus ladaniferus. Biochem Biophysical Res Commun. 2009; 389(1): 145-149.

[23] Attaguile G, Caruso A, Pennisi G, Savoca F. Gastroprotective effect of aqueous extract of Cistus incanus L in rats. Pharm Res. 1995; 31(1): 29-32.

[24] Yesilada E, Gurbuz I, Ergun E. Effects of Cistus laurifolius L flowers on gastric and duodenal lesions. J Ethnopharmacol. 1997; 55(3): 201-211.

[25] Yesilada E, Gurbuz I, Shibata H. Screening of Turkish anti-ulcerogenic folk remedies for anti-Helicobacter pylori activity. J Ethnopharmacol. 1999; 66(3): 289-293.

[26] Ustun O, Ozcelik B, Akyon Y, Abbasoglu U, Yesilada E. Flavonoids with anti-Helicobacter pylori activity from Cistus laurifolius leaves. J Ethnopharmacol. 2006; 108(3): 457-461.

[27] De Pascual Teresa J, Urones JG, Marcos IS, Barcala PB, Garrido NM. Diterpenoid and other components of Cistus laurifolius. Phytochemistry. 1986; 25(5): 1185-1187.

[28] Demirezer LO, Guvenalp Z, Kuruuzum-Uz A, Kazaz C. Labdane-type diterpenes from Cistus creticus L. Planta Med. 2007; 73(9): 953-953.

[29] Chaves N, Rios JJ, Gutierrez C, Escudero JC, Olias JM. Analysis of secreted flavonoids of Cistus ladanifer L. by highperformance liquid chromatography particle beam mass spectrometry. J Chromatogr A. 1998; 799(1-2): 111-115.

[30] Danne A, Petereit F, Nahrstedt A. Proanthocyanidins from Cistus incanus. Phytochemistry. 1993; 34(4): $1129-1133$.

[31] Danne A, Petereit F, Nahrstedt A. Flavan-3-ols, prodelphinidins and further polyphenols from Cistus salvifolius. Phytochemistry. 1994; 37(2): 533-538.

[32] Saracini E, Tattini M, Traversi M, Vincieri F, Pinelli P. Simultaneous LC-DAD and LC-MS determination of ellagitannins, flavonoid glycosides, and acyl-glycosyl flavonoids in Cistus salvifolius L. leaves. Chromatographia. 2005; 62(5-6): 245-249.

[33] Fernández-Arroyo S, Barrajón-Catalán E, Micol V, Segura-Carretero A, Fernández-Gutiérrez A. High-performance liquid chromatography with diode array detection coupled to electrospray time-of-flight and ion-trap tandem mass 
spectrometry to identify phenolic compounds from a Cistus ladanifer aqueous extract. Phytochem Anal. 2010; 21(4): 307-313.

[34] Santagati NA, Salerno L, Attaguile G, Savoca F, Ronsisvalle G. Simultaneous determination of catechins, rutin, and gallic acid in Cistus species extracts by HPLC with diode array detection. J Chromatogr Sci. 2008; 46(2): 150-156.

[35] Vogt T, Gul PG. Accumulation of flavonoids during leaf development in Cistus laurifolius. Phytochemistry. 1994; 36(3): 591-597.

[36] Gürbüz P, Demirezer LÖ, Güvenalp Z, Kuruüzüm-Uz A, Kazaz C. Isolation and structure elucidation of uncommon secondary metabolites from Cistus salviifolius L. Rec Nat Prod. 2015; 9(2): 175.

[37] Tohge T, de Souza LP, Fernie AR. On the natural diversity of phenylacylated-flavonoid and their in planta function under conditions of stress. Phytochem Rev. 2017;1-12.

This is an open access article which is publicly available on our journal's website under Institutional Repository at http://dspace.marmara.edu.tr. 